\title{
cenas dO AMOR INDÍGENA
}

\author{
Betty Mindlin
}

\section{I - À MODA IKOLEN GAVIÃO (1)}

O jovem adolescente vem voltando da caçada, sorvendo os perfumes da floresta, trilhando veredas familiares. Carrega nas costas, num trançado de folhas verdes de paxiúba, preso à cabeça por uma faixa de embira, seu trunfo de dois mutuns. Tem as mãos livres para tocar uma flautinha de bambu, kutirap. Vai compondo, tomado pela imagem da mocinha que ama. É filha de sua irmã, e desde crianças há no ar algo que os une; sabem que têm o melhor laço de parentesco para casar, ou seja, tio materno com sobrinha. Mas há poucos meses é que os olhares que trocaram prometem muito mais, expressando o desejo que palavras e gestos ainda não concretizaram.

A melodia ecoa pelo verde... As notas e sons correspondem a palavras, que a mocinha ao longe ouve e identifica, maravilhada (2):

Como uma fruta madura

Escorrendo rio de sumo

Quero abrir minha amada

Lamber a pele de humo

Doçura de polpa escura

Ela sabe que o canto lhe é destinado, pois o jovem caçador, antes de partir, indicou para onde ia, mostrando o instrumento musical, fálico, embora pequeno, distinto das grandes flautas grossas de festas dos seres do além, os Guyaney.

Trêmula de alegria, ela corre para pegar seus arquinhos iridinam, comparáveis a um violino em miniatura, com uma só corda. Ela encosta na boca a madeira de um arquinho, e com a mão esquerda junta a corda do segundo à do primeiro. Os sons mudam quando ela mexe nas cordas com os dedos. Só as mulheres o tocam, para as cantigas de amigo. E ela manda a resposta envolta em notas:

O vento sopra amor

Do bambu do meu amado.

Vem me dar o que caçou...

No seu nariz o enfeite

É a pluma de arara,

É vermelha e armada.

Ele é grande furador

Ele é o melhor caçador

Da minha fenda rosada

Nela deixarei arriada

Sua pena de cor

Mole mole aninhada

No meu corpo acolhedor.

Se ela não o amasse, poderia insultá-lo em sua melodia, dizendo à mãe dele que outro é seu namorado. 
O namoro dos Ikolen é envolto em ternura e respeito. O sentimento deve arrebatar os amantes, quase à moda do amor cortês medieval, fazendo crescer o desejo. Um homem não pode tomar uma mulher de modo precipitado - ela é que deve assentir, quando não puder mais conter o anseio de viver o corpo. Ele não pode assustar a alma da moça, $t i$ (uma das almas, pois os Ikolen têm várias almas). Se traduzíssemos, seria deixar fluir Eros e as emoções, sem nada forçar... ao menos na teoria. As meninas Ikolen, diz-se, por vezes começam o relacionamento sexual antes da menarca. Serão as crianças tão pacientes que obedeçam aos princípios do amor?

De todo modo, quando casam, pode acontecer que os cônjuges deitem-se juntos por muito tempo-alguém falou em um ano-sem consumar a união. É a intensidade da paixão brotando, experimento de corpo e alma muito particular. Amor tantra, disciplina? Se os Ikolen nos contassem mais sobre seus amores...

Eles orgulham-se muito de sua arte de amar. Criticam a paixão desmedida ou incontida, imediatista, de outros povos.

II - PAIXÃO ÍNDIA. OS PAITEREY SURUÍ “O centro das atenções de uma mulher é o marido. Está sempre voltada para ele, agradando, desejando ser apreciada, aprovada. Ela o enfeita, pinta seu corpo, cata piolhos, acorda para acender o fogo quando ele manda. Dia e noite, nunca o deixa. E não é só dele que cuida, mas de toda a família: deve plantar, colher, cozinhar, alimentar, trazer água, limpar, acalentar e banhar crianças. É artista, faz os adornos do marido, os colares, cintos, as redes brancas ou vermelhas de urucum”.

"Nunca paramos ociosas, inativas... Cortar os coquinhos de tucumã, lixá-los para que fiquem brilhantes, leva horas e horas, vamos fazendo sempre que dá, nos minutos entre outras tarefas. Se o marido vai a reuniōes, à cidade, a outras ocas, vamos também. Mesmo para defecar, o marido nos segue, e parece natural obedecermos juntos aos imperativos do corpo. Estamos prontas para atender aos pedidos dele, e como ficamos próximas, nossa fidelidade não é posta em dúvida. É verdade que ele tem várias esposas, mas quer sempre saber tudo o que faz a preferida, fica inquieto mesmo com poucas horas ou dias de ausência".

"Tenho muitos filhos e netos, soube ser amorosa. Aprendi com minha mãe. O marido Paiter é ciumento; temos que evitar mexericos, ou comentários falsos sobre como nos comportamos. Sempre há pessoas maldosas que nos acusam de namorar fora do casamento. Mas não posso imaginar minha vida sem meu tio materno. Cresci com ele, catei seus piolhos, arranquei micuins, fiz carícias e massagens, e ele gosta muito de mim, me quer sempre.

Vocês sabem que marido e mulher Paiter até para ir ao mato costumam ir juntos? É quase como se fôssemos um só corpo... É bonito, porque mulher é amor, é a companhia mais preciosa que o marido tem, éa terra primeira para que ele possa plantar, caçar, ser um guerreiro e chefe, ela é a ternura e firmeza que fazem a alegria de um homem".

"Como todas as meninas, quando fiquei akapeab, menstruada pela primeira vez, fui morar alguns meses na oca pequenina, ao lado da oca maior da nossa grande família, onde viviam meu pai, seus irmãos, as mulheres de cada um deles. Só via minha mãe, os irmãos pequenos, alguns parentes, mas ouvia suas conversas. Akapeab pode traduzir-se como "sentada na esteira", de resguardo. Nesses meses vamos ficando branquinhas, a pele clara, pois não devemos tomar sol, só saímos cobertas por palha (ou, hoje em dia, cobertores), para as necessidades diárias. $\mathrm{O}$ banho tomamos dentro, com água que nos trazem e esquentamos, fazendo um buraco para que se escoe. Nesse tempo isolado aprendemos com nossas mães e avós os trabalhos de uma mulher, fiamos, fazemos cestas, ouvimos como devemos ser com os homens e futuros maridos. Temos que ficar paradas, para formar corpo, ir engordando. Não podemos comer qualquer comida, muitos alimentos são proibidos".

"O casamento acontece quando a menina está forte, pronta. $\mathrm{O}$ noivo, que é seu tio materno, entra na oca pequena, cria desenhos negros de jenipapo no belo corpo adolescente e se retira para esperála fora. Ela sai do resguardo da oca pequena e é levada pelo pai, mãe, irmãos, até onde está o marido”.

"Sabemos, nesses meses, que vamos casar com nosso tio materno. Avós, mães, tios pais, podem ajudar no nosso preparo como esposas. Nosso tio é que nos acompanha desde pequenas. Quando a irmã engravida, o homem trata dela, faz roça, leva comidas que pode comer, até findar a reclusão pós-parto. Ele torce para que a irmã tenha uma menina, com quem vai casar; se nascer um menino, ele considera que saiu perdendo".

Esses e outros depoimentos foram feitos em língua indígena e traduzidos por professores indígenas Suruí Paiter em 2007, em uma oficina de educação, destinada a definir o conteúdo das escolas bilíngues atuais (3).

Os participantes, homens e mulheres, eram jovens professores e Korubey, os mais velhos, não letrados e nem sempre falantes de português, mas considerados sábios que orientariam os assuntos tradicionais a incorporar nas escolas.

Os velhos e as velhas, os primeiros professores de cultura que permitiram documentar o seu mundo, há trinta anos, nos anos setenta, desfilavam para o público os costumes antigos. Falavam na língua indígena, e os jovens traduziam para consultores e educadoras presentes. Corroboraram o que está descrito nos livros sobre os Suruí, Nós Paiter (4), Vozes da origem (5) e Diários da floresta (6) -, que todos têm, e embora não saibam ler, ouviram em voz alta, em português. Pajés e seres do além, mitos, cooperação econômica, guerra, artes, parentesco, roça, caça, amor, casamento, tabus de alimentação e regras de comportamento, desde a menarca e menstruação até o casamento, o pós-parto, o resguardo, a doença e o luto brotavam nas reuniōes. Correspondiam, exatamente, ao que foi apreendido nos registros gravados há décadas - uma experiência fascinante, de uma pesquisa antiga condensada agora em poucos dias e muitas falas.

Entusiasmados, os intérpretes professores iam bordando e elaborando os discursos, que incluíam numerosas mulheres. Surgia um modelo da mulher virtuosa. "Vejam que bonito o que ela nos conta! Que mulher amorosa com o marido!", proclamava um deles, encantado.

A presença contínua da esposa atenta, companheira disponível para qualquer tarefa, pode afigurar-se aos nossos hábitos individu- 
alistas como subserviência e submissão feminina, e nos chocamos de ouvir as ordens de marido, os objetos jogados ao chão para que elas apanhem, eles sempre reis ou deuses acolhidos em harém. O ciúme imenso que têm todos, e não apenas dos laços conjugais, e sim de todos os afetos, exige provas contínuas. Mas a dedicação entre esposos, a permanente contiguidade, a definição pelo casamento e parentesco de um laço eterno criam um ser único com corpo duplo. Marido e mulher ficam indispensáveis um ao outro, a vida é em si o par amoroso. Há muitas separaçōes e novos casamentos, mas são numerosos os casais duradouros, que estão juntos desde a infância.

III - PAIXÃO E TRANSGRESSÃO PAITER Há paixão desesperadora entre os índios? "Amor de trapo e farrapo", como diria Paulo Vanzolini, sem remédio, pelo qual vale incorrer na mais grave transgressão? $\mathrm{Ou}$, só há o amor eterno, fiel, leal, da infância à velhice? Questōes que nos intrigam em qualquer sociedade ou época histórica, e que entre os Suruí encontram um campo fértil para suposiçōes.

Os Paiterey são apaixonados, afetivos, acolhedores. Generalizar é perigoso, mas eles dão sempre a impressão de sinceros, de terem prazer nas amizades. Gostam de quem chega, são curiosos sobre o alheio, percebem o caráter do visitante, adoram conversar.

O clima social entre eles é mais que propício ao amor. Há laços definidos entre as pessoas, baseados no parentesco; cada um tem seu lugar assegurado no conjunto. Pelas regras de parentesco, o melhor casamento é o do tio materno com a sobrinha; em seguida entre primos cruzados, num conceito não apenas biológico, mas classificatório. (Ou seja, segundo a classificação do sistema. As definições de "irmãos" e "primos" são extensas, irmãos sendo filhos de duas mulheres irmãs ou dois homens irmãos, e primos sendo os filhos de um irmão e uma irmã). Desde a mais tenra infância, as crianças sabem com quem podem casar. A menina é criada e mimada pelo tio materno. Os vários tios disputam-na entre si, nos acordos com os pais da noiva cobiçada. A familiaridade entre os amantes é dada, estabelecida, não são estranhos e conhecem-se desde sempre. Se têm a sorte de se amar, de combinar personalidades e peles, vivem unidos até bem velhinhos. Há belos exemplos de casais mais velhos cheios de filhos, amorosos, bastante fiéis, segundo o que é possível observar, sempre juntos, gentis e solícitos entre si. Parecem felizes, sólidos, sem inquietação.

Não se nota insegurança ou solidão afetiva como um traço característico da vida social, embora haja sempre exceções. Solteiros e solteiras de qualquer idade são muito raros entre os índios. Amor e sexo são necessários, valorizados, impensável sua ausência, como seria impossível viver sem alimento.

Tudo impulsiona para o casamento e para o amor. Ter filhos e mulheres é a riqueza: quanto mais numerosos, maiores as roças, os bens, o poder político, baseado no parentesco e no domínio mágico da pajelança. As mulheres, trocadas, negociadas, permitem tecer uma rede ampliada na comunidade. Elas, é claro, não são apenas objeto. São lindas, nuas, danadinhas, com olhares convidativos, espontâneas, voltadas para namorar, sem proibições ou culpas aparentes. Para os homens, há poligamia instituída, explícita, um ou outro chega a ter cinco esposas. Para as mulheres, os namoros sem-vergonhas, camuflados, mas fáceis de perceber, pelos presentes e colares que os amantes recebem.

O corpo e o sexo não têm mistério, além daquele que lhes infunde a alma e o sentimento ("O corpo em si mistério: $\mathrm{O}$ nu: cortina de outro corpo, jamais desvendado", diz Carlos Drummond de Andrade). As crianças vêem partos, provavelmente observam cópulas, começam cedo a vida sexual - as mulheres, talvez antes da menarca. Os animais são dissecados à vista de todos, pois a anatomia é um conhecimento de muitos, ao contrário do que se passa conosco. Meninos pequenos acompanham o nascimento de um nenê da irmã e jogam fora a placenta. Matéria e reprodução são integradas ao quotidiano, fluem com simplicidade. O corpo é explorado, as pessoas tocam-se, catam piolhos e micuins, massageiam-se, deitam juntos nas redes, as peles se abraçam com gosto.

Seria essa uma visão do paraíso amoroso? De certo modo sim, se compararmos com inúmeras sociedades que tanto controlaram e puniram contatos físicos. Mas, seria preciso temperar a resposta com muitos outros ângulos da vida social...

Lembremos, por exemplo, do maior tabu para o amor, quando este infringe os princípios dos laços amorosos institucionais. É o casamento entre irmãos, crime grave que afeta toda a comunidade, trazendo males para todos. Transgredir essa norma é desgraça pesada, com consequências para a vida futura. As almas dos incestuosos são castigadas com grandes terrores no Marameipeter, o caminho depois da morte, e extinguem-se para sempre, ao que se diz.

É no incesto, porém, que surgem as grandes paixōes. E nos mitos, o incesto desencadeia a criação: da arte, dos astros, dos adornos.

Ciúme, casamentos forçados, brigas e pancadaria toldam a visão do paraíso. Só há liberdade para as mulheres se tiverem apoio de pais e parentes, ou a sorte de ter prazer quando amam dentro das leis. Ainda assim, as rebeldes vão atrás do próprio desejo, fogem, não se submetem, amam vários homens às escondidas, orgulham-se dos feitos amorosos múltiplos.

Seria preciso descrever casos concretos dos amores proibidos, pedir aos amorosos Paiter que os contem ou escrevam sobre eles. Mas isso são outros capítulos, para outras noitadas.

Para finalizar, lembremos que tudo o que foi exposto sobre esse e os outros povos é a vida antiga, hoje transformada. Misturam-se agora os costumes, trazendo mudanças para as normas amorosas e para o papel das mulheres.

Betty Mindlin é doutora em antropologia pela Pontificia Universidade Católica de São Paulo, autora de Mitos indígenas, Ática, 2006 e outros livros em coautoria com narradores indígenas. 


\section{NOTAS E REFERÊNCIAS BIBLIOGRÁFICAS}

1. O item "À moda Ikolen Gavião" foi exposto no "Encontro Internacional de Psicopatologia Transcultural", realizado na Universidade Federal do Pará, Belém. Abril de 2010.

2. Mindlin, B.; Tsorabá; Digut; Sebirop; Catarino e outros narradores Gavião Ikolen. Couro dos espíritos. São Paulo: Senac/Terceiro Nome. 2001 (português, tradução de gravações na língua).

3. A oficina foi organizada pelo Fórum das Organizações do Povo Suruí Paiter e participei como antropóloga, debatendo temas culturais que poderiam ou deveriam constar de um currículo escolar. Devo a gentileza do convite aos índios e às assessoras do projeto de formação de professores indígenas, Laíde Ruiz Ferreira, Maria do Carmo Barcellos e Linete Ruiz Ferreira.

4. Mindlin, B. Nós Paiter. Petrópolis: Vozes. 1985.

5. Mindlin, B. e Narradores indígenas. Vozes da origem. Rio de Janeiro/ São Paulo: Record. 2007 (reedição).

6. Mindlin, B. Diários da floresta. São Paulo: Terceiro Nome. 2006. 